\title{
Design of Students' Evaluation of Teaching: The Case of Sripatum University
}

\author{
R. Sanitya and S. Sinjindawong
}

\begin{abstract}
This study aimed to develop and design the Students' Evaluation of Teaching (SET) at Sripatum University. The development also includes two works: 1) Development of the SET form, its validity was considered by three experts, and the consistency was considered between the questions on the objective of the evaluation or IOC. Then it was tested on 41 students to analyze the reliability by Cronbach's Alpha Coefficient. 2) Design and develop the SET report is consistent with the new evaluation and the expert's recommendations. Then, a sub-groups meeting to conclude the job. Results are as follows:
\end{abstract}

1). There are three parts to the SET form as follows: Part 1: General information, Part 2: The Instructor's Teaching Competency Evaluation, and Part 3: Other suggestions. The consistency between the questions on the objective of the evaluation or IOC0.5.This means that all questions are consistent with the objectives that can be applied to reality and 0.732 Cronbach's Alpha Coefficient of the SET form is at a good level of reliability.

2). The SET report is divided into two main parts. 1) Percentage of students' assessment report and 2) The Instructor's Teaching Competency Evaluation report which is two levels: 1) Faculty the SET report. 2) Individual the SET report is divided into five sections as follows 2.1) Frequency and percentage of students' assessment, 2.2) Frequency and percentage of students' self-assessment, 2.3) Percentage and average of the SET by parts, 2.4) Percentage and average of the SET by items, and 2.5) Students' feedback.

Index Terms - Design, students' evaluation of teaching, evaluation.

\section{INTRODUCTION}

The Students' Evaluation of Teaching (SET) is a mirror image of the teaching activities of teachers. The results of the SET are useful to improve the teaching of teachers to be more effective and to be beneficial to the management plan for the development of the education system as a whole, throughout the entire use as the information can be used to make decisions. Therefore, the SET performance can provide feedback to teachers and administrators [1], [2].

Now, the SET measures each university's progress. The implementation of computer technology and internet network system was used to evaluate the teaching performance [3]. Sripatum University, Thailand has a policy to promote and develop the teaching and learning of teachers in the university which has a regulatory system for the teaching of teachers by STE. It also has established Teaching and Learning Support and Development Center (TLC) to develop the SET.

Manuscript received November 30, 2015; revised March 1, 2016.

R. Sanitya and S. Sinjindawong are with the Sripatum University, Thailand (e-mail: Rugsapon.sa@spu.ac.th, sirinthorn.si@spu.ac.th).
The Condition of Quality Assurance (QA) of the university is to use the information to improve the development of the instructors has changed. The SET is not able to needs of user. So, bring develop The SET.

\section{OBJECTIVE}

This study aimed to develop and design the SET. The development also includes two works:

1) Development of the SET form at Sripatum University, Thailand.

2) Design and develop of the SET report is consistent with the new evaluation.

\section{LITERATURE REVIEW}

The SET is particularly common in United State higher education, as P. Seldin [4] states that SET is used in personnel decisions by 86 percent of higher education institutions in the United State. A significant amount of research is devoted to the issue of validity of SET instrument [5]. Empirical studies indicate that a well-constructed and score-validated SET instrument can serve as a useful indicator of teaching effectiveness.

The Professional Teachers of Teaching and Learning

The goal of the development of the SET is "the professional teachers of teaching and learning", The approach relies on the Professional Teaching Standards for Higher Education synthesized and developed by S. Sinjindawong [6] (Fig. 1). This includes the features of the professional eight as follows:

1) Content and Pedagogy, teachers understand the knowledge content and the in-depth concept of the subject. This includes how to search the knowledge structure of science and knowledge of the content. The teacher creates a learning experience for each student. Content and knowledge using information.

2) Planning Instruction, teachers can plan designed for teaching that is based on the content of knowledge based on the different characteristics of the learner, independent learning skills of the students of the course. And community context. The plan outlines the progress and achievement of students.

3) Effectiveness of Instruction, teachers can use this to teach different strategies that aim to provide students with critical thinking, creative thinking, problem solving, and learning and growing constantly. Teachers understand the nature of the environment that can change the dynamics and improve teaching methods suited to each learner. 
4) Teaching Diverse Classes, teachers understand the difference of the features and capabilities of the learner, and that they can develop to learn as a person in the context of the social, economic, culture, language and experience of the forum. The experienced instructors use this to teach learners to achieve maximum learning.

5) Assessment, teachers can understand the assessment during the study and evaluate the summary to determine the learner as this can track the progress of the learner to measure the development of the learning and the results. In the assessment, teachers can decide the information about the curriculum and teaching effectiveness. Including improving learning for students.

6) Learning Environment, teachers can structure the learning environment for safety and well-being which is to facilitate the emotional well-being, risk reduction, education incentives, inspiration and to achieve personal goals for students.

7) Professionalism, Leadership and Advocacy, teachers have anethical response to the learning of the learner to promote professionalism, provide the opportunity to be a leader in the community, to learn and support the learner the parent or guardian including career promotion in the future to the learner.

8) Collaborative and Communication, teachers are able to communicate with the students and the people involved by maintaining a cooperative relationship with knowledge. The teacher works with a team of professionals, learners, parents, community representatives and stakeholders.

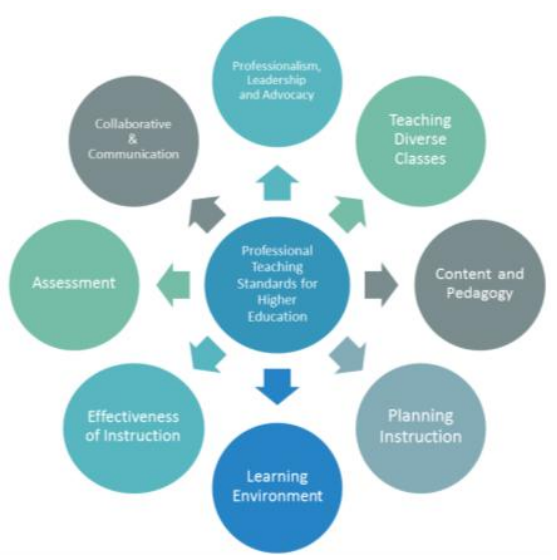

Fig. 1. Professional teaching standards for higher education.

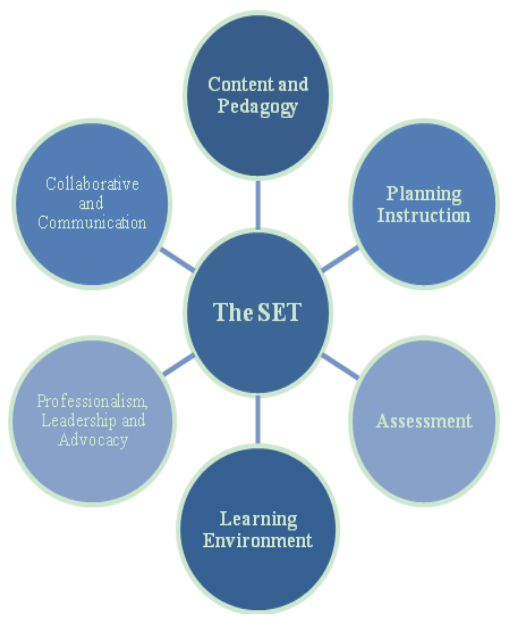

Fig. 2. Conceptual framework.
The development of the SET as analyzed and synthesized by the Professional Teaching Standards for Higher Education, literature review (Document and Research), and the Original SET. Bring to the development of the SET as follows (Table I) and shown the conceptual framework (Fig. 2).

\begin{tabular}{|c|c|c|}
\hline $\begin{array}{c}\text { Professional Teaching } \\
\text { Standards for Higher } \\
\text { Education }\end{array}$ & $\begin{array}{l}\text { Original } \\
\text { SET }\end{array}$ & Revised SET \\
\hline 1. Content and Pedagogy & $\checkmark$ & $\begin{array}{l}\text { 1. Content and } \\
\text { Pedagogy }\end{array}$ \\
\hline 2. Planning Instruction & $\checkmark$ & \multirow{3}{*}{$\begin{array}{ll}2 . & \text { Planning } \\
\text { Instruction } & \end{array}$} \\
\hline 3. Effectiveness of Instruction & $\checkmark$ & \\
\hline 4. Teaching Diverse Classes & $\checkmark$ & \\
\hline 5. Assessment & $\checkmark$ & 3. Assessment \\
\hline 6. Learning Environment & $\checkmark$ & $\begin{array}{cc}4 . & \text { Learning } \\
\text { Environment } & \\
\end{array}$ \\
\hline $\begin{array}{l}7 . \quad \text { Professionalism, } \\
\text { Leadership and Advocacy }\end{array}$ & $x$ & $\begin{array}{l}\text { 5. Professionalism, } \\
\text { Leadership and } \\
\text { Advocacy }\end{array}$ \\
\hline $\begin{array}{l}\text { 8. Collaborative and } \\
\text { Communication }\end{array}$ & $x$ & $\begin{array}{l}\text { 6. Collaborative and } \\
\text { Communication }\end{array}$ \\
\hline
\end{tabular}

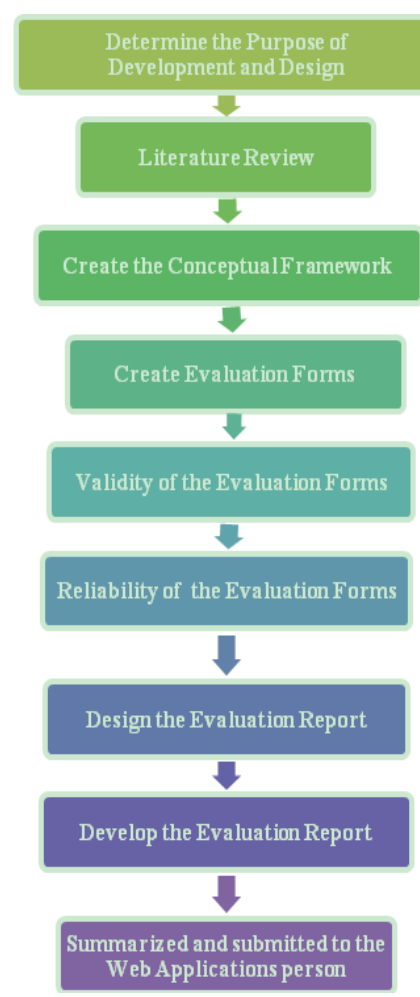

Fig. 3. The development and design of the SET process.

\section{Methodology}

Design of SET: the case of Sripatum University, Thailand also includes two works (Fig. 3):

1) Development of the SET form, according to the Professional Teaching Standards for Higher Education.

The development of the SET form, its validity was considered by three experts (the experts in Measurement and Assessment, Educational Research, and Educational Administration), after that, the consistency was considered between the questions on the objective of the evaluation or Index of Item Objective Congruence (IOC). And then it was test on 41 students from the $2^{\text {nd }}$ to $4^{\text {th }}$ years of the School of 
Communication Arts, Sripatum University, Thailand to analyze the reliability by Cronbach's Alpha Coefficient.

2) Design and develop of the SET report, after completion of the SET form. Therefore, the design and development of the SET report is consistent with the revised SET (new evaluation) and the expert's recommendations. Then, sub-groups meeting with Quality Assurance Manager and Software Developer on four occasions to conclude the job.

\section{RESUlTS}

Results of development and design of the SET are as follows:

1) Development of the SET form, the SET, there are three parts to the SET form as follows:

Part 1: General information of seven questions of which this part is about the course such as subject, section and instructor's name. In addition to the self-assessment of the students there are tests, quizzes, frequency of admission, etc.

TABLE II: THE INDEX OF ITEM OBJECTIVE CONGRUENCE (IOC)

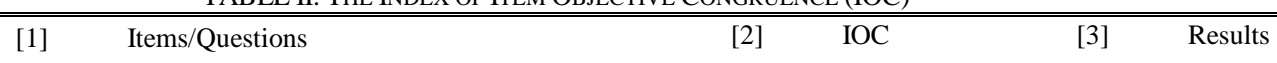

1. Content and Pedagogy

[5] 1. The instructor explained the ...

[8] 2. The instructor taught all the ...

[11] 3. The instructor provided ...
[6] $\quad 1.00$

[9] $\quad 1.00$

[12] $\quad 1.00$
[7] applies to reality

[10] applies to reality

[13] applies to reality

2. Planning Instruction

[15] 4. The instructor had a good ...

[16] $\quad 1.00$

[17] applies to reality

[18] 5. The instructor used various sources ...

[19] $\quad 0.66$

[20] applies to reality

3. Assessment

[22] 6. The instructor employed various ...

[23] $\quad 1.00$

[24] applies to reality

[25] 7. The instructor informed the students ...

[26] $\quad 1.00$

[27] applies to reality

4. Learning Environment

[29] 8. The instructor employed the teaching ...

[30] $\quad 0.66$

[31] applies to reality

[32] 9. The instructor introduced books...

[33] $\quad 1.00$

[34] applies to reality

[35] 5. Professionalism, Leadership and Advocacy

[36] 10. The instructor provided students...

[37] $\quad 0.66$

[38] applies to reality

[39] 11. The instructor integrated professional...

[40] $\quad 1.00$

[41] applies to reality

6. Collaborative and Communication

[43] 12. The instructor used polite and proper...

[44] $\quad 1.00$

[45] applies to reality

[46] 13. The instructor could control his/her...

[47] $\quad 1.00$

[48] applies to reality

[49] 14. The instructor was available to...

[50] $\quad 1.00$

[51]

applies to reality

Note: IOC $>=0.5$ means the questions are consistent with the objectives and can be applied to reality

TABLE III: THE CRONBACH'S ALPHA COEFFICIENT

\begin{tabular}{|c|c|c|c|c|}
\hline$[52]$ & [53] & [54] & [55] & $\alpha$ \\
\hline [56] The Students' Evaluation of Teaching (SET) & [57] 41 & [58] 14 & [59] & 0.732 \\
\hline
\end{tabular}

Part 2: The instructor's teaching competency evaluation of 14 questions of six parts (Content and Pedagogy, Planning 
Instruction, Assessment, Learning Environment, Professionalism, Leadership and Advocacy, and Collaborative and Communication).

Which have responses which correspond to the Likert scale (Level of Opinion are: 5 refers to totally agree, 4 refers to mostly agree, 3 refers to agree, 2 refers to quite disagree, and 1refers to totally disagree).

Part 3: Other suggestions for teaching development.

The consistency between the questions on the objectives of the evaluation or IOC 0.5 . This means that all questions are consistent with the objectives and can be applied to reality (Table II) and 0.732 Cronbach's Alpha Coefficient of the SET form is at a good level of reliability (Table III).

2) Design and develop of the SET report, the format of the SET report is divided into two main parts: Part 1: Percentage of students' assessment report and Part 2: The instructor's teaching competency evaluation report (Fig. 4).

(1) The percentage of students' assessment report.

This part reports the number of registered students, number of students' assessment and percentage of students' assessment of the individual teachers. Also brings percentage of all teachers in the faculty which were grouped into three levels (more than $80 \%, 50$ to $80 \%$, and less than $50 \%$ ). The report can be viewed on screen as a PDF file or can be downloaded as a PDF file (Fig. 5).

(2) The instructor's teaching competency evaluation report. This part splits the report into two levels:

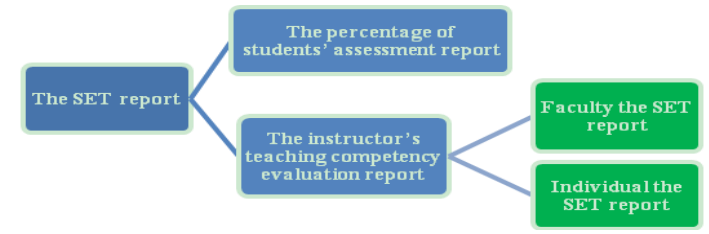

Fig. 4. The design of the SET report.

3) Faculty the SET report, this reports the average score and standard deviation score of the instructor's teaching competency evaluation for all teachers in the faculty ( minimum score $=1$ and maximum score $=5$ ). Moreover, the average score is calculated as a percentage for ease of use (Fig. 6). The report can be viewed on screen as a PDF file or can be downloaded as a PDF file.

4) Individual the SET report, this will be in five sections as follows:

Section 1: Frequency and percentage of students' assessment by course and section. This section will report the description of the courses taught which include ID of subject, subject, section (study group), type of subject (theory and laboratory), teaching day, time, classroom of subject, number and percentage of students registered, assessment and none assessment, etc. (Fig. 7). Also the report can be viewed on screen as a PDF file or can be downloaded as a PDF file. The report in this section relates to the questions in part 1 of the SET.

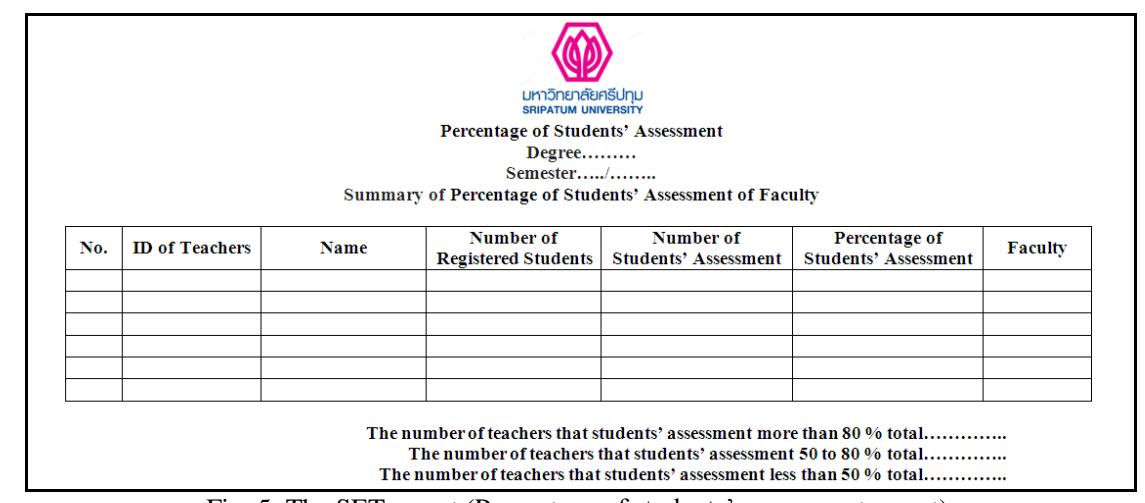

Fig. 5. The SET report (Percentage of students' assessment report).

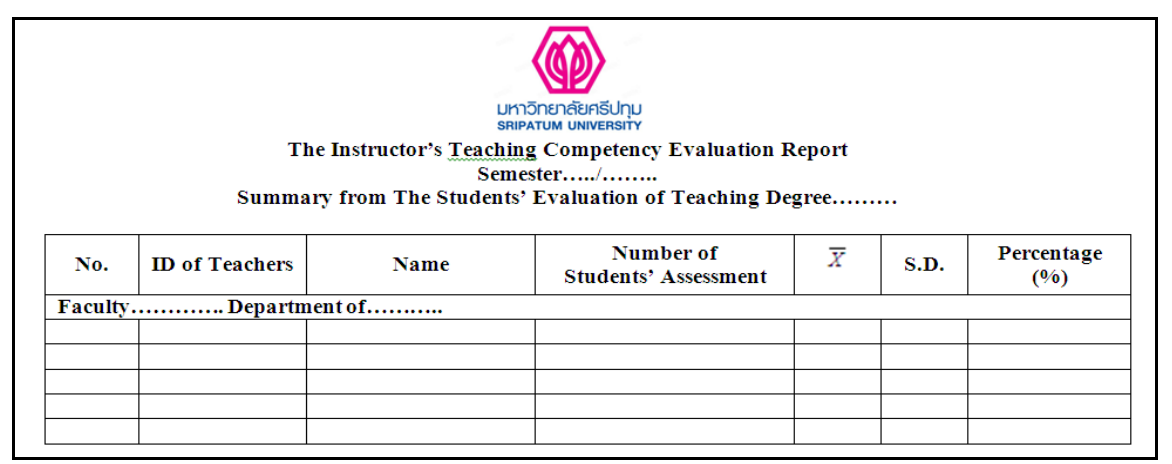

Fig. 6. The SET report (The instructor's teaching competency evaluation report, faculty report).

Section 2: Frequency and percentage of students' assessment and self-assessment. Section II shows the description of the courses (ID of subject, section (study group), type of subject (theory and laboratory), and number of student's assessment. Also, shown is student's assessment such as frequency and percentage of how often the instructor was punctual by arriving and departing the class on time (the frequency: always, sometimes and never), was the instructor properly attired? (yes/no), and, were there quizzes? (yes/no). For the students' self-assessment such as frequency and 
percentage of how often they attended classes? (the frequency: every class, 7-9 times, 4-6 times, and less than 3 times),(Fig. $8)$. The report can be viewed on screen as a PDF file or can be downloaded as a PDF file. The report in this section relates to the questions in part 1 of the SET.

\begin{tabular}{|c|c|c|c|c|c|c|c|c|c|c|c|c|}
\hline \multicolumn{13}{|c|}{ Section 1 Frequency and Percentage of Students Assessment by Course and Section } \\
\hline \multirow{3}{*}{$\begin{array}{l}\text { ID of } \\
\text { Subject }\end{array}$} & \multirow{3}{*}{ Subject } & \multicolumn{2}{|c|}{ Type of Subject } & \multirow{3}{*}{ Date } & \multirow{3}{*}{ Time } & \multirow{3}{*}{ Classroom } & \multicolumn{5}{|c|}{ Number of Students } & \multirow{3}{*}{ Total } \\
\hline & & \multirow{2}{*}{ Theory } & \multirow{2}{*}{ Lab } & & & & \multirow{2}{*}{$\begin{array}{c}\text { Number of Registered } \\
\text { Students }\end{array}$} & \multicolumn{2}{|c|}{ Assessment } & \multicolumn{2}{|c|}{ Not yet } & \\
\hline & & & & & & & & Frequency & Percentage & Frequency & Percentage & \\
\hline \multirow[t]{2}{*}{ EEG351 } & \multirow[t]{2}{*}{$\begin{array}{l}\text { Electrical } \\
\text { Power Systems }\end{array}$} & 01 & & M & $08.30-11.20$ & $11-1201$ & & & & & & \\
\hline & & 90 & & $\mathrm{M}$ & $14.50-17.40$ & $11-1202$ & & & & & & \\
\hline \multicolumn{13}{|c|}{ Total of Subject } \\
\hline \multirow[t]{2}{*}{ EEG456 } & $\begin{array}{l}\text { Power System } \\
\text { Protection }\end{array}$ & 01 & & $\mathrm{H}$ & $08.30-11.20$ & $11-1201$ & & & & & & \\
\hline & & 09 & & $\mathrm{H}$ & $14.50-17.40$ & $11-1202$ & & & & & & \\
\hline
\end{tabular}

Fig. 7. The SET report (The instructor's teaching competency evaluation report, Individual teacher report; section 1).

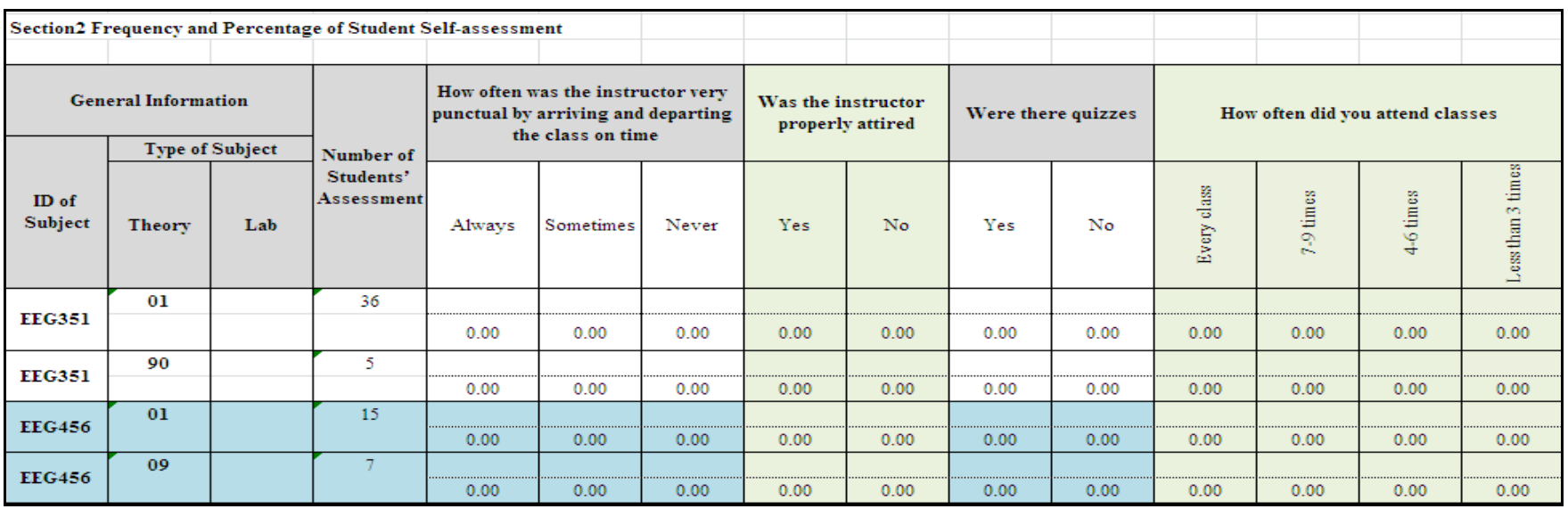

Fig. 8. The SET report (The instructor's teaching competency evaluation report, Individual teacher report; section 2).

\begin{tabular}{|c|c|c|c|c|c|c|c|c|c|c|c|c|c|c|}
\hline \multicolumn{15}{|c|}{ Section 3 Percentage, Arerage, and Atandard deriation of the SET by Parts } \\
\hline \multirow{3}{*}{$\begin{array}{c}\text { ID of } \\
\text { Subject }\end{array}$} & & & \multirow{3}{*}{$\begin{array}{l}\text { Number of } \\
\text { Students' } \\
\text { Assessment }\end{array}$} & \multirow{3}{*}{ Parts } & \multirow{3}{*}{5} & \multirow{3}{*}{4} & & \multirow{3}{*}{\multicolumn{2}{|c|}{2}} & \multirow{3}{*}{\multicolumn{2}{|c|}{1}} & & \multirow{3}{*}{ Mean } & \\
\hline & \multicolumn{2}{|c|}{$\begin{array}{l}\text { Type of } \\
\text { Subject }\end{array}$} & & & & & \multirow{2}{*}{3} & & & & & \multirow{2}{*}{ total } & & \multirow{2}{*}{ S.D. } \\
\hline & $\begin{array}{c}\begin{array}{c}\text { Theor } \\
y\end{array} \\
\end{array}$ & Lab & & & & & & & & & & & & \\
\hline \multirow{14}{*}{ 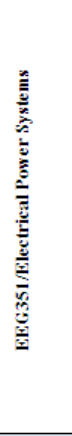 } & \multirow{6}{*}{01} & & \multirow{6}{*}{36} & 1.Content and Pedagogy & 0.00 & 0.00 & 0.00 & 0 & 0.00 & 0 & 0.00 & & 4.87 & 0.36 \\
\hline & & & & 2.Planning Instruction & 0.00 & 0.00 & 0.00 & 0 & 0.00 & 0 & 0.00 & & 4.54 & 0.75 \\
\hline & & & & 3.Assessment & 0.00 & 0.00 & 0.00 & 0 & 0.00 & 0 & 0.00 & & 4.26 & 0.87 \\
\hline & & & & 4. Learning Environment & 0.00 & 0.00 & $0.00=$ & 0 & 0.00 & 0 & 0.00 & & 4.33 & 0.82 \\
\hline & & & & $\begin{array}{l}\text { 5.Professionalism, Leadership and } \\
\text { Advocacy }\end{array}$ & 0.00 & 0.00 & 0.00 & 0 & 0.00 & 0 & 0.00 & & 4.11 & 1.00 \\
\hline & & & & 6.Collaborative and Communication & 0.00 & 0.00 & 0.00 & 0 & $0.00^{\top}$ & 0 & 0.00 & & 4.74 & 0.52 \\
\hline & \multicolumn{4}{|r|}{$\begin{array}{c}\text { Total } \\
\end{array}$} & 0.00 & 0.00 & 0.00 & 0 & 0.00 & 0 & 0.00 & & 4.52 & 0.76 \\
\hline & \multirow{6}{*}{90} & & \multirow{6}{*}{5} & 1.Content and Pedagogy & 0.00 & 0.00 & 0.00 & & 0.00 & & 0.00 & & 4.80 & 0.41 \\
\hline & & & & 2.Planning Instruction & 0.00 & 0.00 & 0.00 & & $0.00^{\prime}$ & & 0.00 & & 4.90 & 0.32 \\
\hline & & & & 3.Assessment & 0.00 & 0.00 & 0.00 & & 0.00 & & 0.00 & & 4.40 & 0.84 \\
\hline & & & & 4.Learning Environment & 0.00 & 0.00 & 0.00 & & 0.00 & & 0.00 & & 4.90 & 0.32 \\
\hline & & & & 5.Professionalism, Leadership and Advocacy & 0.00 & 0.00 & 0.00 & & 0.00 & & 0.00 & & 4.40 & 0.70 \\
\hline & & & & 6.Collaborative and Communication & 0.00 & $0.00^{\top}$ & 0.00 & & $0.00^{\top}$ & & 0.00 & & 4.47 & 0.52 \\
\hline & \multirow{2}{*}{\multicolumn{4}{|c|}{ Total }} & 0.00 & 0.00 & 0.00 & & 0.00 & & 0.00 & & 4.64 & 0.57 \\
\hline & & & & 1 of Subject & 0.00 & 0.00 & 0.00 & & 0.00 & & 0.00 & & 4.54 & 0.74 \\
\hline
\end{tabular}

Fig. 9. The SET report (The instructor's teaching competency evaluation report, Individual teacher report; section 3 ).

Section 3: Percentage, average and standard deviation of the SET by parts. Section 3 shows the description of the courses (ID of subject, section (study group), type of subject (theory and laboratory), and number of student's assessment. The key of this section is the instructor's teaching competency which is in six parts and includes: content and pedagogy, planning instruction, assessment, learning environment, professionalism, leadership and advocacy, and collaborative and communication. The report shows the frequency and percentage of instructor's teaching competency which is in six parts and shows the average score and standard deviation score (minimum score $=1$ and maximum score = 5) (Fig. 9).
But, the report needs to be downloaded as a Microsoft Excel file only. The report in this section relates to the questions in part 2 of the SET.

Section 4: Percentage, average, and standard deviation of the SET by items. In section 4 , the key of the report is the instructor's teaching competency by items or questions (14 questions). The report shows the frequency and percentage of instructor's teaching competency, all of the questions and shows the average score and standard deviation score (minimum score $=1$ and maximum score $=5$ ) all of the questions (Fig. 10). But, the report needs to be downloaded as a Microsoft Excel file only. The report in this section relates 
to the questions in part 2 of the SET.

Section 5: Student's feedback by course and section. The final section of the SET report shows comments or suggestions from students for teaching development (Fig. 11).
The report can be viewed on screen as a PDF file or can be downloaded as a PDF file. The report in this section relates to the questions in part 3 of the SET.

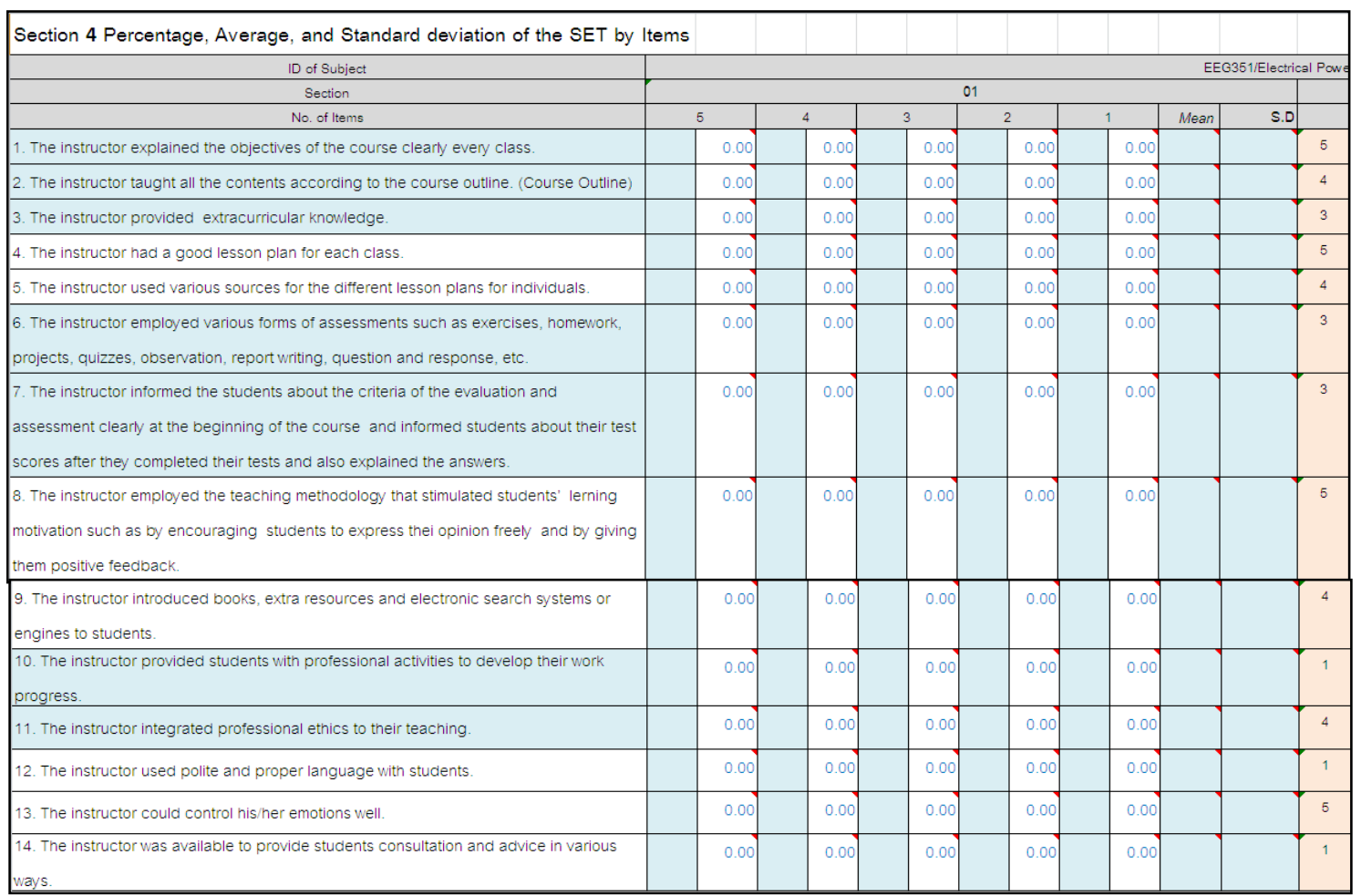

Fig. 10. The SET report (The instructor's teaching competency evaluation report, individual teacher report; section 4).

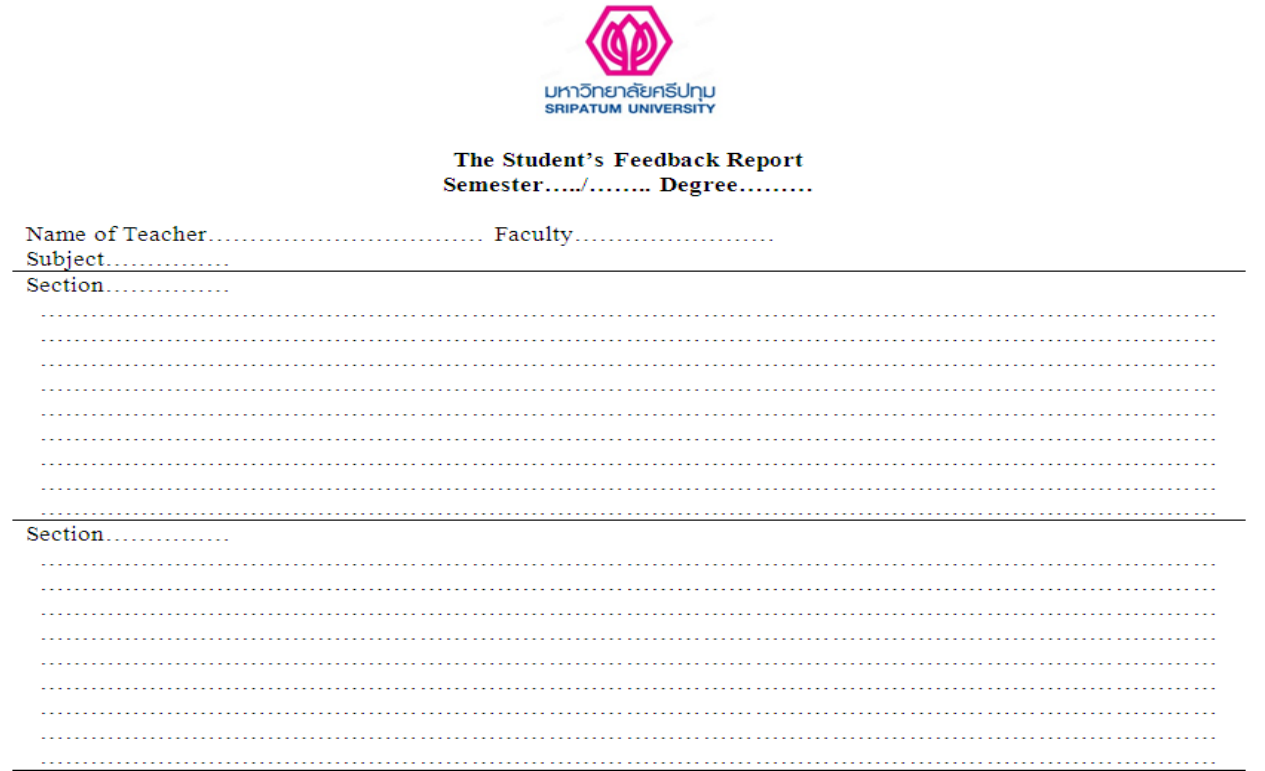

Fig. 11. The SET report (The instructor's teaching competency evaluation report, Individual teacher report; section 5).

\section{DISCUSSION AND CONCLUSION}

This study aimed to develop and design the SET to relates to needs of user, The SET form develop according to the Professional Teaching Standards for Higher Education. And then it was test on 41 students which is enough to the test. However, all students are only in bachelor degree.

The results of the reliability of the SET form accept Cronbach's Alpha Coefficient at 0.70 [7], that mean the SET form is at a good level of reliability. This relates to the study of B. Jadkhong (2005) [8] who studied the online Teaching Assessment System of Uttaradit Rajabhat University and found the system used the Cronbach's Alpha Co-efficient to assess and improve the reliability of teaching assessment. The result of the Alpha Co-efficient is 0.76 for teaching skill, 0.82 for teaching plan skill, and 0.83 for relationship between teacher and student. The Alpha Co-efficient shows that teaching assessment is reliable and relates to the study of $\mathrm{N}$. Saelea, O. Naiyapatana and S. Solgosoom (2011) [9] who studied the development of a teaching evaluation form for the bachelor-level degree at Silpakorn University. It was found 
that the factors of the teaching evaluation form for a bachelor's degree at Silpakorn University was based on the guidelines of Marsh (1987) from the synthetic evaluation data of all teaching faculties of the university, had good reliability and good discrimination. The factors were the value of student learning, enthusiasm of the instructor, teaching preparation, learning environment, physical interactions in the classrooms, friendliness of the instructor, the ability to transfer knowledge of the instructor, appropriate criteria to measure and evaluate, assignment, workload and difficulty.

For the results of the SET report, the format of the SET report to related with SET form. It's divided into two main parts: Part 1: Percentage of students' assessment report and Part 2: The instructor's teaching competency evaluation report. The SET report makes an easy to used and easy to understand for the needs of teachers in development of teaching.

The university has a goal for the teachers "the professional teachers of teaching and learning". In addition to the support and development in Classroom Action Research (CAR), books, etc., the SET is also an important part in the development of teaching and learning which includes the development of the teachers because the teachers teaching will be evaluated. The results of the SET are useful to improve the teaching of teachers to be more effective. So, the revised SET can be used for the development of teacher to be professional teachers of teaching and learning. However, it is required to inform the teachers so they know that they will be evaluated on the issues so they can develop themselves to be professional teachers of teaching and learning. For the revised SET will be brought into the SET system instead of the original SET by the software developer. In addition, set the key user and software developer for System Administrator. For activation is expected to open (on the system) in the next semester after the test system is finished.

\section{REFERENCES}

[1] K. Suwannaraj, "The development teacher's assessment system on the internet network of Pibulsongkram Rajabhat," Pibulsongkram Rajabhat University, 2006.

[2] N. Posing, "The development of online assessment system," Graduate School Journal Surindra Rajabhat University, vol. 1, no. 1, pp. 37-51, 2007.

[3] C. Papattha, "Development of evaluation system of teaching via network," King Mongkut's Institute of Technology North Bangkok, 2006.
[4] P. Seldin, "The use and abuse of student ratings of professors," The Chronicle of Higher Education, vol. 39, no. 46, p. A40, 1993.

[5] H. Wachtel, "Student evaluation of college teaching festiveness: A brief review," Assessment and Education in Higher Education, vol. 23, pp. 191-211, 1998.

[6] S. Sinjindawong, "A development of professional teacher in higher education: A case study of Sripatum University," Global Academic Network, Apr. 23-26, 2014, Temple University, Tokyo, Japan. 2014.

[7] J. 1. Cronbach, Essentials of Psychological Testing, New York: Haper and Row Publishing, 1970.

[8] B. Jadkhong, "Online teaching assessment system of Uttaradit Rajabhat University," Master Independent Study, Dept. Computer Science, Chaingmai Univ., Chaingmai, THA, 2005.

[9] N. Saelea, O. Naiyapatana, and S. Solgosoom, "The development of a teaching evaluation form for the bachelor-level degree at Silpakorn University," Silpakorn University Journal, vol. 31, no. 2,pp. 85-105, 2011.

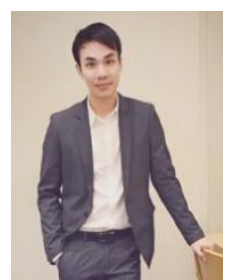

Rusapon Sanitya was born in Nan province, Thailand, on May 23, 1987. For his educational background is the master degree in demography, College of Population Studies, Chulalongkorn University, Bangkok Thailand in 2012 and the bachelor degree in social research, Faculty of Social Science, Naresuan University, Thailand in 2009.

He worked as a researcher of Teaching and Learning Support and Development Center, Sripatum University, Bangkok Thailand from 2015 to present. In 2013, he worked as a research assistant of the understanding social barriers to coping with and adapting to extreme climate events project, College of Population Studies, Chulalongkorn University Thailand, etc. He published some articles.

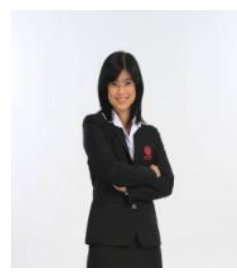

Sirinthorn Sinjindawong was born in Supanburi province, Thailand, on January 21, 1972. for her background is the doctoral degree in educational measurement and evaluation, Faculty of Education Chulalongkorn University, Thailand in 2010 and the master degree in educational measurement, Srinakharinwirot University, Thailand and the bachelor degree in general science, Pranakorn Sri Ayutthaya Rajabhat University, Thailand.

She was teaching in research methodology course for Ph.D. students in educational administration, and project management and evaluation course for M.Ed. graduate program. And also, she was teaching undergraduate courses for research methodology to business, accounting, economy, and airline business students, bachelor program. She had 18 research projects. She had received research fund from National Research Council of Thailand, that she was a plan director on the topic "Development of teacher at basic education level on the assessment of high level learning" and researcher fund in Thai Health Promotion Foundation 4 projects, and the Association of Private Higher Education Institutions of Thailand, too. She published some articles. 